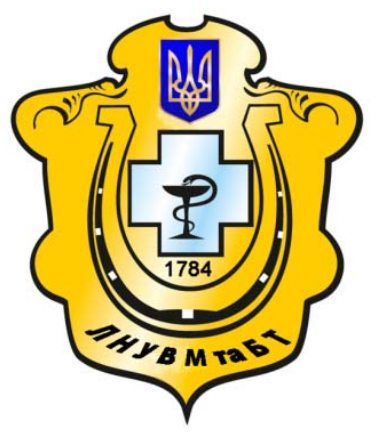

Науковий вісник Львівського національного університету ветеринарної медицини та біотехнологій імені С.3. Гжицького

Scientific Messenger of Lviv National University of Veterinary Medicine and Biotechnologies named after S.Z. Gzhytskyj

doi:10.15421/nvlvet7609

ISSN 2519-2701 print

ISSN 2518-1327 online

http://nvlvet.com.ua/

УДК 338.439.5

\title{
Економічна оцінка стану та тенденцій розвитку м'ясного скотарства Львівської області
}

\author{
А.В. Гримак \\ opanovich@ukr.net \\ Львівський державний університет внутрішніх справ, \\ вул. Городоцька, 26, м. Львів, 79007, Украӥна
}

\begin{abstract}
Наведені у статті результати дослідження містять інформаџію про ситуаџію на ринку продукції м'ясного скотарства, а також фактори, які стимулюють або стримують розвиток галузі. Виявлено окремі невідповідності при заготівлях, переробиі, формуванні иіни, попиті на продукцію галузі, поведінці споживача, усунення яких сприятиме поліпшенню фактичного стану та стабілізаиї розвитку м'ясного скотарства. В свою чергу і зміни у нормативно-правовому забезпеченні ще не в повній мірі проявились на завершенні формування ринкового середовища м'ясного скотарства.

Невід'ємною умовою ефективного господарювання в галузі м'ясного скотарства є активне використання переваг ринкових відносин. Виробничо-економічні зв'язки у м'ясному підкомплексі АПК повинні базуватись на взаємопогодженій співпрачі на стадіях виробництва сировини, ї̈ переробки та споживання готової м'ясної продукиії, а також створенні інтегрованих виробничих формувань. Одним із вирімальних факторів поступального розвитку галузі м'ясного скотарства $\epsilon$ кормова база та нарощування селекиійного ядра. Відносини між сільськогосподарськими товаровиробниками і переробними підприємствами повинні базуватись на об'єктивно-обтрунтованій ціновій політиці, яка виключала б ціновий диспаритет у відносинах учасників м'ясного підкомплексу АПК.

Ключові слова: ринок, м'ясне скотарство, аграрний сектор, тендениії, економічна оцінка.
\end{abstract}

\section{Экономическая оценка состояния и тенденций развития мясного скотоводства Львовской области}

\author{
А.В. Гримак \\ opanovich@ukr.net \\ Львовский государственный университет внутренних дел, \\ ул. Городоикая, 26, г. Львов, 79007, Украина
}

\begin{abstract}
Приведенные в статье результаты исследования содержат информацию, относящуюся к ситуации на рынке продукции мясного скотоводства, а также факторы, которые стимулируют или сдерживают развитие отрасли. Установлены отдельние несоответствия при заготовках, переработке, определении иены и спросе на продукиию отрасли, поведении потребителя, устранение которых будет способствовать улучшению фактического состояния и стабилизации развития отрасли мясного скотоводства. В свою очередь и изменения в нормативно-правовом обеспечении еще не в полной мере проявились на завершении формирования рыночной среды мясного скотоводства.

Неотъемлемым условием эффективного хозяйствования в отрасли мясного скотоводства является активное использование преимуществ рыночных отношений. Производственно-экономические связи в мясном подкомплексе АПК должны базироваться на взаимосогласованном сотрудничестве на стадиях производства сырья, его переработки и потребления готовой мясной продукиии, а также создании интегрированных производственных формирований. Одним из решающих факторов поступательного развития отрасли мясного скотоводства является кормовая база и нарашивание селекиионного ядра. Отношения между сельскохозяйственными товаропроизводителями и перерабатывающими предприятиями дол-
\end{abstract}

Citation:

Hrymak, A.V. (2017). Assessment of economic development and trends beef cattle lviv region. Scientific Messenger LNUVMBT named after S.Z. Gzhytskyj, 19(76), 43-46. 
жны базироваться на объективно обоснованной иеновой политике, которая исключала бы иеновой диспаритет в отношениях участников мясного подкомплекса АПК.

Ключевые слова: рынок, мясное скотоводство, аграрный сектор, тенденции, экономическая оченка.

\title{
Assessment of economic development and trends beef cattle lviv region
}

\author{
A.V. Hrymak \\ opanovich@ukr.net \\ Lviv State University of Internal Affairs \\ Horodotska Str., 26, Lviv, 79019, Ukraine
}

Given in article research results provide information about the situation on the beef cattle production, and factors that promote or hinder the development of the industry. Revealed some inconsistencies in the procurement, processing, pricing, demand for the products of industry, consumer behavior, the removal of which will improve the actual state and stabilization of beef cattle. In turn, changes in the regulatory provision is not yet fully evident at the completion of the beef cattle market environment.

An essential condition for effective management in beef cattle is active markets, the benefits-term relationship. Industrial and economic ties in meat subcomplex AIC should be based on the work of mutual co-production stages in raw and processed meat consumption of finished products as well as creating integrat-Rowan production units. One of the decisive factors in the progressive development of beef cattle industry is increasing and forage breeding nucleus. The relationship between agricultural producers and processing enterprises, we should be based on objective and reasonable pricing, which would exclude the price disparity in the relationship beef sub APC members.

Key words: market, beef cattle, agriculture, trends, economic assessment.

\section{Вступ}

Львівська область займає особливе місце серед інших областей України щодо поступального розвитку агропромислового виробництва, зокрема і м'ясного скотарства (Hrymak, 2007; Trynko and Hrymak, 2009). Розвитку цієї галузі сприяють об'єктивні передумови, насамперед природно-кліматичні, трудові, економічні для функціонування i розвитку ринку продукції м'ясного скотарства, а також історичні, адже населення області завжди тяжіло до розвитку індивідуальних приватних господарств з розведення різних видів тварин та птиці, в т. ч. м'ясного напрямку (Kandyba, 1993; Mesel-Veseliak and Mazurenko, 1999). I не випадково в аграрному секторі Львівської області більшу питому вагу займає виробництво продукції тваринництва. Однак разом із позитивними тенденціями намітились і проблемні, що позначаються і на розвитку м'ясного скотарства. Серед основних варто виділити невідповідність цін при закупівлях і комплектуванні резервів продовольства, низьку купівельну спроможність населення, суттєве здорожчання енергоносіїв, нееквівалентні відносини між сільським господарст- вом і переробною промисловістю, нестимулююча кредитна система i т. ін. Потребує удосконалення цілісна система взаємовідносин учасників маркетингової лінії від товаровиробника м'ясних ресурсів (сировини) до переробника і споживача готової продукціï.

\section{Матеріал і методи досліджень}

Методологія дослідження базувалася на методах пізнання, аналізу, статистики, оцінки відносин між виробниками-переробниками-споживачами.

\section{Результати та їх обговорення}

Виробництво м'яса, зокрема яловичини, в області, як і загалом по Україні, змінилося у зв'язку зі зміною форм власності і господарювання та реформуванням крупних, в т. ч. спеціалізованих, господарств громадської власності. За цих умов виробництво м'яса всіх видів було стабільним або динамічно зростало, що не можна сказати про виробництво м'яса яловичини (табл. 1).

Таблиия 1

Обсяги виробництва м'яса всіх видів, в т. ч. яловичини (тис. т) (всі категорії господарств)

\begin{tabular}{|l|c|c|c|c|c|c|c|c|c|c|c|c|}
\hline \multicolumn{1}{|c}{ Показник } & 2005 & 2006 & 2007 & 2008 & 2009 & 2010 & 2011 & 2012 & 2013 & 2014 & 2015 & $\begin{array}{c}2015 \\
\text { до } 2005, \%\end{array}$ \\
\hline $\begin{array}{l}\text { Виробництво м'яса всіх } \\
\text { видів у ж. в. (тис. т) }\end{array}$ & 124,5 & 135,0 & 146,9 & 154,3 & 156,0 & 165,1 & 166,8 & 174,0 & 188,3 & 176,4 & 170,3 & 136,8 \\
\hline $\begin{array}{l}\text { Виробництво м'яса } \\
\text { яловичини у ж. в. (тис. т) }\end{array}$ & 68,4 & 69,1 & 68,3 & 64,0 & 60,1 & 55,0 & 56,0 & 46,7 & 51,1 & 48,0 & 46,3 & 67,7 \\
\hline
\end{tabular}

Джерело: дані Головного управління статистики у Львівській області

Тенденція до скорочення виробництва м'яса яловичини намітилась із 2010 року, на що вплинуло ряд факторів. Серед них варто виділити відсутність достатнього практичного досвіду на етапах переходу до ринкової моделі розвитку, що певною мірою призвело до розбалансування економічних зв'язків між виробниками м'яса, переробниками, реалізаторами та споживачами і поставило м'ясне скотарство перед необхідністю реформування і переходу до нових форм господарювання. При цьому відповідно відбувався 
перехід до роботи в нових умовах господарювання й усвідомлення ринкового вибору, як і те, за якою ціною, на яких умовах і кому реалізувати продукцію, якою мала б бути співпраця із переробними підприємствами. Треба враховувати і те, що з 2014 року як в області, так і Україні на загальний стан розвитку галузі м'ясного скотарства, як і інших, позначилась ситуація 3 анексією Криму та частини Донецької i Луганської областей, яка загострила проблеми.

Варто відзначити і те, що припинення державних закупівель поставило виробників продукції м'ясного скотарства у залежність від переробних підприємств, які скуповували та й скуповують м'ясну сировину за порівняно низькими цінами. Аналіз підтверджує і те, що серед причин, які впливають на розвиток м'ясного скотарства, є постійний ріст затрат і собівартості продукції, недостатній рівень дотацій при вирощуванні та заготівлі худоби, запровадження вільних цін, які не відшкодовують затрати в галузі і не впливають на іiі рентабельність. Суттєвий вплив на ефективність галузі має продуктивність тварин м'ясного стада. Тут важливим $\epsilon$ відновлення селекційно-племінної роботи, розведення м'ясних порід тварин, організація повноцінної їх годівлі. Вивчення ситуації в галузі м'ясного скотарства свідчить, що джерелом яловичини на м'ясному ринку $\epsilon$ виключно молочне скотарство. Водночас вираженою $є$ тенденція скорочення поголів'я корів, що позначається на чисельності й відгодівельного стада (табл. 2).

Поголів'я ВРХ, в т. ч. корів у всіх категоріях господарств на 1 січня 2017 р. (тис. гол.)

\begin{tabular}{|l|c|c|c|c|c|c|c|c|c|c|c|c|c|}
\hline \multicolumn{1}{|c}{ Показник } & 2005 & 2006 & 2007 & 2008 & 2009 & 2010 & 2011 & 2012 & 2013 & 2014 & 2015 & 2016 & $\begin{array}{r}2016 \\
\text { до } 2005, \%\end{array}$ \\
\hline Поголів'я ВРХ & 395,0 & 362,7 & 353,3 & 317,5 & 299,8 & 283,7 & 251,9 & 237,6 & 250,5 & 240,4 & 210,3 & 203,4 & 51,5 \\
\hline у т.ч. корови & 261,0 & 235,4 & 215,1 & 192,1 & 177,7 & 171,7 & 161,7 & 155,9 & 152,4 & 146,7 & 136,7 & 129,7 & 49,7 \\
\hline
\end{tabular}

Джерело: дані Головного управління статистики у Львівській області

Викладені проблеми позначились на розвитку м'ясного скотарства як складової економіки сільськогосподарської галузі, адже м'ясо і продукція м'ясної промисловості по праву прирівнюється до стратегічних ресурсів.

Базуючись на набутому історичному досвіді, сприятливих природно-кліматичних умовах, практичних напрямах, які реалізуються при здійсненні реформування галузі м'ясного скотарства, можливо відпрацьовувати і розглядати заходи, реалізація яких сприятиме підвищенню ефективності виробництва продукції м’ясного скотарства у Львівській області. В цих заходах доцільним було б виділити:

- створення нових, інтегрованих підприємств, кооперативів, об'єднань i т. ін. 3 виробництва, переробки i реалізації м'яса, в т. ч. яловичини i м'ясних продуктів;

- практичне нарощування поголів'я худоби м'ясних порід;

- створення, відповідно до потреб, кормових ресурсів;

- виправданим є нарощування племінного ядра у стадах товарних господарств, розведення адаптованих до зональних умов порід;

- використання менеджменту в пошуках вигідних, стабільних ринків реалізації м'ясної худоби та м'ясопродуктів;

- спільно виробникам, переробникам, реалізаторам узгодити шляхи удосконалення параметрів розвитку ринку яловичини на перспективу;

- розглядати слід і маркетингові чинники, які сприяють поєднанню інтересів як виробників, так i споживачів;

- одним із першочергових завдань $є$ курс на призупинення тенденції скорочення поголів'я корів, відповідно великої рогатої худоби на відгодівлі і дорощуванні та подальше його нарощування.
Завдання не $з$ легких, оскільки за рахунок власного відтворення стада в короткий період вирішити його складно, тому не виключений навіть імпорт;

- важливо вивчити і використовувати можливості кооперування. Розглядати виробничу кооперацію із сільськогосподарськими товаровиробниками слід як засіб ефективного і гарантованого забезпечення не тільки сировиною, а й готовою продукцією.

- застосовувати об'єктивно-виважену цінову політику на всьому ланцюгу: виробництво-переробкареалізація. Відпрацювати програму доступного, довгострокового, у т. ч. й пільгового, кредитування сільськогосподарських і переробних підприємств різних форм власності, включаючи і особисті сільські господарства для зміцнення їх матеріальної бази, поліпшення якісних характеристик поголів'я тварин, вирішення тих питань, які безпосередньо впливають на ефективність i продуктивність м'ясного скотарства.

За наявних природно-кліматичних та економічних умов для Львівської області актуальним є створення на ринку умов для підвищення пропозиції на м'ясо, в т. ч. яловичини, з метою задоволення попиту на дану продукцію. При цьому треба враховувати, що переважна більшість споживачів надають перевагу, насамперед якісній і екологічній продукції. У пропозиції такої продукції суттєві економічні пріоритети має Львівська область, зокрема за рахунок наявності екологічно чистих й порівняно дешевих і продуктивних кормових угідь, переважаючої концентрації поголів'я тварин у господарствах населення, розвитку підприємств переробної галузі різної потужності та власності, що $є$ важливим і у зменшенні виробничих витрат на готову продукцію.

Здійснення наведених заходів позитивно позначиться не тільки на виробництві м'яса, а й на його попиті та рівнях споживання i, що важливо, на рентабельності галузі м'ясного скотарства. Результати ана- 
лізу свідчать, що в області, як і в Україні загалом, забезпечується стабільність обсягів споживання м'яса і м'ясних виробів (табл. 3).

Рівень споживання м'яса різних видів, в т. ч. i м'яса яловичини, в області, порівняно із показниками по Україні, повною мірою можна пояснити зменшенням обсягів виробництв м'яса яловичини в загальному виробництві м'яса та рівнем доходів потенційних споживачів.
Для Львівщини стабільний аграрний сектор є базою для поступального економічного розвитку, а це означає: агропромисловий комплекс 3 його могутнім природним і трудовим потенціалом повинен стати серйозним конкурентом для виробників сільськогосподарської продукції та продуктів харчування, в т. ч. продукції м'ясного скотарства в Україні.

Таблиия 3

Споживання м'яса і м'ясопродуктів в розрахунку на одну особу в середньому за місяць (кг)

\begin{tabular}{|l|c|c|c|c|c|c|}
\hline \multicolumn{1}{|c|}{ Показник } & 2010 & 2011 & 2012 & 2013 & 2014 & 2015 \\
\hline Споживання по Україні & 5,1 & 5,1 & 5,0 & 5,1 & 4,9 & 4,6 \\
\hline Споживання по Львівській області & 4,2 & 4,1 & 4,3 & 4,4 & 4,1 & 4,1 \\
\hline
\end{tabular}

Джерело: дані Головного управління статистики у Львівській області

\section{Висновки}

Невід'ємною умовою ефективного господарювання в галузі м'ясного скотарства $є$ активне використання переваг ринкових відносин. Виробничоекономічні зв'язки у м'ясному підкомплексі АПК повинні базуватись на взаємопогодженій співпраці на стадіях виробництва сировини, іiі переробки та споживання готової м'ясної продукції, а також створенні інтегрованих виробничих формувань. Одним із вирішальних факторів поступального розвитку галузі м'ясного скотарства $\epsilon$ кормова база та нарощування селекційного ядра. Відносини між сільськогосподарськими товаровиробниками і переробними підприємствами повинні базуватись на об'єктивнообгрунтованій ціновій політиці, яка виключала б ціновий диспаритет у відносинах учасників м'ясного підкомплексу АПК.

Перспективи досліджень. Будуть продовжуватись дослідження з оцінки ефективності реформування галузі м'ясного скотарства.

\section{Бібліографічні посилання}

Trynko, R.I., Hrymak, A.V. (2009). Rynok produktsii miasnoho skotarstva: stan, perspektyvy rozvytku: Monohrafiia. Lviv: TzOV «Liha Pres» (in Ukrainian).

Hrymak, A.V. (2007). Otsinka efektyvnosti vyrobnytstva produktsii miasnoho skotarstva silskohospodarskymy pidpryiemstvamy riznoi formy vlasnosti u Lvivskii oblasti. Ekonomika: Problemy teorii ta praktyky: Zb.nauk.pr. Dnipropetrovsk: DNU. 1, 130-140 (in Ukrainian).

Kandyba, V.M. (1993). Stratehiia i taktyka zbilshennia vyrobnytstva yalovychyny. Tvarynnytstvo Ukrainy. 5/6, 2-4 (in Ukrainian).

Mesel-Veseliak, V.Ia., Mazurenko, O.V. (1999). Ekonomichni vidnosyny uchasnykiv intehrovanoho formuvannia. Rozvytok hospodarskykh formuvan i orhanizatsiia vyrobnytstva $\mathrm{v}$ ahrarnii sferi APK. K.:UAAN IAE (in Ukrainian).

Holovne upravlinnia statystyky u Lvivskii oblasti. Statystychni dani (in Ukrainian).

Стаття надійшла до редакиії 12.02.2017 